\title{
Diversionary Dragons, or "Talking Tough in Taipei": Cross-Strait Relations in the New Millennium
}

Yitan Li, Patrick James, and A. Cooper Drury

\begin{abstract}
Much has been written on the triangular, and increasingly high-profile, ChinaTaiwan-US relations. However, scholars have yet to apply Diversionary Theory to the China-Taiwan dyad. DT argues that leaders may resort to international conflict when domestic political and economic situations become troublesome, aiming at directing public attention away from problems at home. While creation of explicit military conflict in the Taiwan Strait by Taipei is deemed quite unlikely, more subtle processes of diversion might be expected instead. This article applies a variant on DT to assess whether leaders in Taipei have used rhetoric about Taiwan independence or unification as a distraction from domestic problems during the years leading up to Taiwan's 2004 presidential election. We find that, as the president's approval sinks, pro-independence rhetoric becomes more likely. Overall, the results of this study confirm extension of DT to the case of Taiwan and encourage further research applied to middle powers.
\end{abstract}

KEYwORDS: diversionary theory, cross-strait relations, China, Taiwan, international conflict, Chinese politics, East Asian politics

uch has been written on the triangular, and increasingly high-profile, China-Taiwan-US relations. ${ }^{1}$ Scholarship is multiplying on the possible nature of a Chinese threat to both territory and shipping lanes, with methods ranging from strategic analysis to simulation (Chambers 2002; Senese 2005). However, scholars have yet to apply Diversionary Theory (DT) to the highly salient ChinaTaiwan dyad. DT argues that leaders may resort to international conflict when domestic political and economic situations are troublesome. The objective is to direct public attention away from problems at home and toward conflict with an external adversary, all to the presumed benefit 
of the ruling elite. While creation of explicit military conflict in the Taiwan Strait by the leadership in Taipei is deemed quite unlikely as a possible means toward quelling internal dissent, more subtle processes of diversion might be expected instead. Specifically, will Taipei's domestic political and economic changes lead to a better or worse relationship with Beijing? In addition, do Taiwan's political parties' positions on cross-strait relations have the potential to "purchase" them a ticket to the presidency during an election?

DT, commonly focused on war but also including other forms of conflict, is now a "major research program in the field and a good example of how a combination of a statistical, formal-theoretic, and case study research can contribute significantly to the cumulation of knowledge" (Levy and Mabe 2004, 65). While valuable in triangulating knowledge as just described, existing DT studies primarily focus on the United States and United Kingdom. The case of China and Taiwan adds significantly to the empirical testing regime for DT. More specifically, Taiwan is located in Asia and is not an "old" democracy, so an assessment of DT in this context represents a qualitative addition to the research program. Furthermore, the issue of independence gets at the core of Taiwan's identity, which is a central matter to both the general public and the elite. Thus, the present test for DT is a very challenging and inherently interesting one. Put differently, will we see something that resembles diversionary behavior from leaders in what is arguably the most sensitive among the substantive policy areas for Taiwan? If so, that would constitute impressive support for DT beyond, as will become apparent, the somewhat mixed record derived from the study of great powers.

What, in sum, does this study intend to contribute to DT? To put it most forcefully, this research demonstrates that DT can apply to foreign policy instruments beyond the threat or use of force while simultaneously taking the theory into the new empirical domain represented by cross-strait relations.

March 2004 marked an important occasion for the Republic of China (ROC) on Taiwan. For just the third time in its history, the ROC directly elected its president. The Democratic Progressive Party (DPP) won the election by a tenuous 0.2 percent margin. The DPP (traditionally known for pro-independence) and the Kuomintang (KMT) (traditionally known for pro-unification) coalitions continue to divide on their positions toward mainland China, the preeminent foreign policy issue. In the meantime, Taiwan continues to experience an economic downturn, with particularly high unemployment, so the domestic situation is problematic. In spite of the difficult economic times, mainland China attracts a large 
amount of investment from Taiwan. Thus, the close and complex connections of the ROC and China effectively blur the line between domestic politics and foreign policy-a genuine case of "linkage politics" as so aptly described in the classic exposition by James Rosenau (1969).

This article applies a variant of DT to assess whether leaders in Taipei used Taiwan independence as a diversion from domestic problems during the years leading up to the 2004 presidential election. Simultaneously, the study also determines if Taiwan's position on crossstrait relations influenced competing parties' prospects in that election.

As a closely related actor, the United States has official and unofficial ties with China and Taiwan, respectively. Political and economic changes in Taiwan and their subsequent influence on cross-strait relations also are anticipated to affect US relations with both China and Taiwan. This research project draws out foreign policy implications for the United States in dealing with Beijing and Taipei, with the greater objective of identifying a path toward more cooperative bilateral and trilateral relations. The conduct of Taiwan itself may be more of a worry to the United States in the context of the strait (Carpenter 2005). In this situation, the client state may use words alone to provoke a rival world power, namely China, and produce a conflict that requires direct US involvement.

\section{A Review of Diversionary Theory}

There is an intermittent literature on DT going back over centuries (Coser 1956; Levy 1989). The core idea of DT is that leaders can have an incentive to pursue diversionary behavior when in trouble at home. When a troubled leader pursues international diversionary activities, the domestic public can be expected to rally around its leader against the outside adversary (Mueller 1973; Ostrom and Simon 1985; Brody and Shapiro 1989; Edwards and Gallup 1990; Morgan and Bickers 1992; James and Rioux 1998). Particularly, a weak domestic economy and sagging public approval rate are prime reasons for leaders to divert attention to an international crisis, including the option of war to boost support (Ostrom and Job 1986; Levy 1989; Russett 1990; James and Oneal 1991; DeRouen 2000).

DT asserts that foreign policy cannot easily be disentangled from domestic politics (James and Oneal 1991; Redd 2005, 134). The theory challenges the traditional realist's position, which conceives of the nation-state as a unitary actor where foreign policy decisionmaking goes through a "black box" and foreign and domestic policies are independent 
of each other (James 1988; Putnam 1988; Mastanduno, Lake, and Ikenberry 1989; Morgan and Bickers 1992; Miller 1995; Morgan and Anderson 1999).

Much attention has been focused on DT and the use of force, particularly by US presidents (James and Oneal 1991; James and Rioux 1998; DeRouen 2000; Meernik 2000). There are several reasons for this research priority. First, data on the primary dependent variable, US presidents' use of military force overseas, are readily available. The most prominent independent variables, which measure economic status, presidential approval rate, and other domestic factors, also are more available for the United States as compared with other actors. Second, because of its power the United States is most capable of challenging other states through military means. Third, as commander in chief, the US president has the capability to act in both foreign policy and military deployment, albeit within constitutional limitations. This concentration of power in one individual makes the assessment of DT more feasible and relevant in the US context.

Research on US presidents and the diversionary use of military force is extensive. Charles Ostrom and Brian Job (1986) find that domestic, political factors are more influential on the president's decision to use military force than characteristics of the international environment from 1949 through 1976. Patrick James and John Oneal (1991) introduce a new indicator, a measure of severity for ongoing international crises, and find that it is associated significantly with use of force by the United States over the same period investigated by Ostrom and Job (1986). James and Oneal (1991) replicate Ostrom and Job's finding and argue that domestic political factors remain most consequential in the president's decision to use force.

Patrick James and Jean-Sébastien Rioux (1998) find that crisis activity increases the president's popularity, albeit by a very small margin. This study also finds, however, that the outcome of the international crisis responded to by the president does not seem to affect presidential popularity. This finding indirectly reinforces the already established importance of domestic factors in explaining presidential standing.

Benjamin Fordham (1998a, 1998b) introduces important nuances into the program of research on DT, particularly as related to economic conditions. Inflation, for example, makes the use of force (a) less likely, because war, if it occurs as a result of diversionary behavior, can increase inflation, but also (b) more likely, because the economic welfare of voters is harmed and may make them more willing to support action abroad. These contradictory effects may end up canceling each other 
out. Unemployment, by contrast, makes force more attractive by reducing costs (a "supply effect") and harming voters (a "demand effect"). Fordham's refinements receive solid support from data analysis of US uses of force from 1949 to 1994. Karl DeRouen (2000) reassesses the key findings from previous data-based DT studies. The results concur with many other research designs (Ostrom and Job 1986; Levy 1989; Russett 1990; James and Rioux 1998) on some economic factors, such as the unemployment and inflation rates, and their influences on presidential use of force. The study also suggests that forceful presidential actions produce a limited boost in approval.

James Meernik (2000) argues that selection effects on presidential use of force may have affected findings from previous studies. Political use of military force is divided into two subsets: those that find evidence of a direct link between domestic conditions and the use of force, and those that argue that the link is conditional (Meernik 2000). Results from Meernik's study suggest that a lack of modeling for the "crisis-generation process" has hindered the evaluation of DT.

As mentioned earlier, studies of DT have focused overwhelmingly on US presidential use of force. Recently, several studies have looked at DT and/or the subsequently related "rally around the flag" effect in the UK. T. Clifton Morgan and Christopher Anderson (1999, 811) apply a revised DT model and argue that their results indicate that British governments "use external aggression as a tool for bolstering their support among the members of their ruling coalition." Brian Lai and Dan Reiter (2005), on the contrary, show a general absence of diversionary effects in the UK.

Clearly, DT remains a viable but controversial theory about foreign policy. Particularly, current empirical testing has been focused on a limited set of countries, with recent studies of Israel and its neighbors effectively expanding the US-based research program to at least one middle power in some depth (Sprecher and DeRouen 2002, 2005). ${ }^{2}$ This rigorous study is an example of paying proper attention to context when attempting to assess DT for a middle power. The basic great power-centric model must be adapted to circumstances. For example, Christopher Sprecher and Karl DeRouen (2005) assess whether Israeli military actions increase as a function of (a) domestic unrest and (b) external threat relationships. Both expectations are met for the period 1948-1998 (Sprecher and DeRouen 2002, 252). Sprecher and DeRouen (2005) also study Israel and consider the number of parties as a proxy for the government's vulnerability. They find that a larger number of parties in the cabinet are more likely to produce hostile actions. 
To sum up, DT is a theory about foreign policy action that also includes a story about effects reverberating at the domestic level, most notably referring to an anticipated rally effect for the chief executive. Two different tests are entailed by these twin expectations and, as will become apparent, that matter is addressed in the research design by a particular choice of statistical estimation. Our extension builds upon the noteworthy finding from a large-n study that even weak states (democracies, in particular) as well as benevolent states can engage in diversionary uses of force (Pickering and Kisangani 2005; Kisangani and Pickering 2007). In addition, our study builds on the approach of Sprecher and DeRouen $(2002,2005)$, which emphasizes the contextual aspects of building a model for a given middle power. In the following section, we explain how and why Taiwan's political rhetoric about China can fit into the framework of DT and also how the theory needs to be adapted to better explain the Taiwan case.

\section{Historical Background and Further Articulation of Diversionary Theory}

An obvious question to get out of the way concerns the validity of this approach as related to Taiwan and China: Are cross-strait relations equivalent to foreign relations? Although the issue is obviously contested, since 1949 both sides of the Taiwan Strait have been exercising de facto sovereignty. Each side in the conflict features an effective government, an active military, a fixed population, and firm territorial control. Both act independently on "domestic" and "international" issues. For the purpose of this article, the fact that both Taiwan and China hold separate policies clearly makes the two actors independent political entities.

A more difficult question is whether DT, with its emphasis on the use of military force or creation of an international crisis as the primary source for diversion, is appropriate to the Taiwan Strait. The use of military force or the creation of any military crisis in the Taiwan Strait on the part of the leadership in Taipei seems unlikely, but certainly not impossible; moreover, political actions modeled by DT might well generate such a crisis, as we show in the next section.

The history of the recent period shows several examples of conflict in the Taiwan Strait. It bears remembering that between 1949 and 1978, Beijing's policy toward Taiwan was to "liberate Taiwan by force [and] ... wash Taiwan in blood" (Wu 1994, 19). China actually had conquered the minor offshore island of Tachen in 1955 and bombarded 
Quemoy in 1955 and 1958 in conjunction with its Taiwan policy during the early years. Taipei, for a certain period after 1949, also perceived military means as the ultimate solution for the Taiwan problem. Chiang Kai-shek asserted a firm belief in "national recovery and national reconstruction" (Copper 1990, 30). Chiang Ching-kuo $(1979,8)$ also believed that the "anti-Communist struggle will never cease until Communism is eliminated from Chinese territory and until the Chinese Communist regime has been destroyed." 3

After the death of Mao, the People's Republic of China (PRC) relaxed its stance on Taiwan and proposed peaceful reunification. China, however, has never renounced the use of force to take the island. Among many other initiatives to promote a peaceful unification, in the early 1980s, PRC leader Deng Xiaoping proposed the "one country, two systems" formula. Hong Kong and Macau came back to Chinese rule in 1997 and 1999, respectively, under this formula, and China has been encouraging Taiwan to accept the same framework with even more autonomy. The ROC, by contrast, has "unilaterally renounced the use of force to unify China, no longer competes with Beijing to represent China in the international community, and now acknowledges that the PRC exercises 'de facto authority' over mainland China" (Hickey 2001, 18).

In the late 1990s, the situation in the Taiwan Strait escalated to near crisis. The private visit to the United States of then Taiwanese president Lee Teng-hui ${ }^{4}$ and his statement about China and Taiwan having "stateto-state" or at least "special state-to-state" relations, angered Beijing (Ross 2006). Furthermore, the PRC authorized live missile tests off Taiwan's coast in 1995 and 1996 in reaction to Taiwan's first presidential election in 1996. The situation became acute enough to prompt the United States to send aircraft carriers to the region to monitor the situation. Nevertheless, China's aggressive military policy soon appeared to backfire. ${ }^{6}$ Taiwan and China both backed down. Since the 1996 missile crisis, both sides have been able to constrain themselves and maintain a very low profile on any military gestures.

By the mid-1990s, there was a strong "Taiwan identity" movement on the island (Ross 2006). The then DPP presidential candidate Chen Shui-bian seized this momentum to run in opposition to the historically dominant KMT. During Taiwan's 2000 election, China did threaten Taiwan verbally. After winning the election, president-elect Chen Shui-bian issued the "Five No's" to placate Beijing. ${ }^{7}$ Beijing, too, soon softened its tone. Furthermore, Beijing has long argued that any possible US military action to help defend Taiwan would not deter China from taking whatever steps it deems necessary to thwart Taiwan independence 
(CNN, December 9, 2003). Beijing, however, has yet to initiate any military actions against Taiwan, which strongly confirms the evolution of the conflict across the strait in the direction of hostile verbiage as opposed to specific applications of force. Although Chen Shui-bian did not spark any military conflict with mainland China during his eight-year rule, the relationship in the Taiwan Strait remained tense.

To sum up, while exchanges and interdependence in the area of low politics-particularly Taiwan's dependence on China-have drawn the adversaries closer together than ever before, potential for conflict remains. On the one hand, overt provocation does not seem likely, but on the other hand, two things are noteworthy: (1) the relationship has in fact been subject to recurrent crises; and (2) even if a direct provocation from either side appears unlikely, it is not impossible that some inadvertent action could have an escalatory effect. Because military actions could be extremely costly and risky, leaders in the Taiwan Strait may use less costly means to engage each other. Leaders in Taiwan might be expected to use their positions on Taiwan's relations with mainland China (independence or unification) to influence their standing in domestic politics, and these actions might very well have the effect of generating crises. ${ }^{8}$ In the next section, we introduce hypotheses, statistical procedures, the data collection process, and variables used to test DT in the cross-strait context.

This represents a shift in focus from DT as applied to hegemonic (US) or great (UK) powers to a middle power (Taiwan), but it also and more importantly expands the range of the theory with regard to foreign policy behavior. The new research design includes signaling and declaratory policy and could be applied to any state with the right set of adjustments to place it in context.

\section{Hypotheses}

Based on the previous discussions, we propose the following hypotheses.

Diversionary Hypotheses

- Diversionary hypothesis. The lower the president's approval rating, the more likely he is to promote Taiwanese independence.

- Misery hypothesis. The higher the inflation and unemployment rates, the more likely the president will be to promote Taiwanese independence. 
- Cordial Relations hypothesis. The more cross-strait visits and trade, the less likely the president will be to promote Taiwanese independence.

The Diversionary and Misery hypotheses derive in a straightforward way from the idea that leaders will want to redirect public attention to more favorable areas. For obvious reasons, an already unpopular leader or one faced with declining economic conditions becomes more likely to engage in such thinking. ${ }^{9}$ An alternative way of thinking also should be acknowledged, and there has been some range of opinion about the effects of executive standing from the early days of aggregate testing onward (Ostrom and Job 1986; James and Oneal 1991). Specifically, it may be the case that a leader with a lot of capital built up, perhaps in the form of either popularity or standard of living, may feel more disposed toward spending it on foreign ventures. A direct way to measure this is through incorporating a basic indicator of overall prosperity. Thus, GDP per capita will be incorporated as a control in the data analysis that follows.

The Cordial Relations hypothesis acknowledges that a Taiwanese president also could benefit from actions that suggest improved relations across the strait. If cross-strait relations are stable, political leaders have no incentive to interrupt the existing political and economic stability for their own interests. Therefore, they should have no incentive to provoke mainland China by promoting Taiwan independence.

\section{Approval Hypotheses}

- Independence hypothesis. The more the president promotes Taiwanese independence, the higher the presidential approval.

- Opposition hypothesis. The greater the opposition's rhetoric, the lower the presidential approval.

- Economy hypothesis. The worse the Taiwanese economy, the lower the presidential approval.

- Visit hypothesis. The more cross-strait visits that occur, the higher the presidential approval.

- Trade hypothesis. The greater cross-strait trade levels are, the higher the presidential approval.

The Independence and Opposition hypotheses are variants on those from DT; in the context of Taiwan, rhetoric about independence takes the place of military force. Regarding the Independence hypothesis, we 
expect the Taiwanese president to act according to the "rally around the flag" effect. Promotion of Taiwan independence serves as an external political diversion or strategic crisis, which subsequently could help to boost domestic popularity. (Data limitations prevent consideration of more subtle effects that would separate out partisans versus voters in general.) As the president promotes more Taiwan independence, the opposition is expected to react negatively to the president's position. As a result, we expect to see the president's popularity drop as the intensity of the opposition rhetoric (pro-unification rhetoric) increases. The Economy hypothesis is a corollary to the preceding Misery hypothesis-that is, worsening economic conditions are likely to lead to lower presidential popularity. Finally, the Visit and Trade hypotheses acknowledge that more cooperative forms of behavior by the president vis-à-vis China also could be rewarded by the public through higher approval based on the belief that Taiwan's standing might be improved through such means as well.

\section{Data, Variables, and Statistical Procedures}

\section{Data and Variables in the Cross-Strait Context}

As explained earlier, a direct military conflict initiated by leaders in Taiwan seems unlikely. Taiwan itself does not have the military capability to launch an offensive against China. Should Taiwan decide to initiate military actions against China, Taiwan would have to secure explicit support from the United States. The willingness and readiness of US involvement depends on calculation of its own strategic interests. An explicit military conflict initiated by Taiwan with US involvement undoubtedly would complicate the Taiwan issue immeasurably. Moreover, both the political risk and the policy risk would be immensely high if leaders in Taiwan initiated direct military conflict with mainland China. ${ }^{10}$ Therefore, a dichotomous variable (Ostrom and Job 1986; James and Oneal 1991) indicating the use of major or nuclear-capable forces would not be proper in the Taiwan case. Instead, we propose an alternative variable: Taiwan's President's Independence or Unification Magnitude (PIUM).

The core of the Taiwan issue is Taiwan's independence. Since Taiwan's first presidential election in 1996, all presidential candidates have had to deal with the issue of Taiwan independence. Former KMT president Lee Teng-hui showed signs of supporting greater Taiwan independence in 1995. Other KMT leaders have adopted a more neutral 
or even pro-China approach by promoting and maintaining the status quo in the Taiwan Strait. During the 2000 presidential election, the proindependence DPP party leader Chen Shui-bian also promoted Taiwan independence and won, although marginally. Chen Shui-bian continued to promote a new Taiwanese identity and independence while in office. During Chen's 2004 reelection campaign, he also promoted a referendum that, if passed, would have been considered provocative by mainland China. ${ }^{11}$ Despite Chen's referendum failure, he managed to win the 2004 election, although with just a 0.2 percent margin. Many argue that the shooting attempt, which injured both Chen Shui-bian and VicePresident Annette Lu on the eve of the presidential election, also swung some "sympathy" votes for the DPP. Nevertheless, the issue of Taiwan independence certainly played an important role in Chen's reelection.

Leaders in Taiwan could use Taiwan's relations with mainland China (independence or unification) as a mere campaign tool to seek the winning of an election or reelection. They also could use their positions on relations with the mainland as a diversion from their domestic problems. Taiwan independence or unification is an important factor that can affect Taiwan's election results and domestic politics. Since Taiwan's first democratic election in 1996, every presidential campaign and many subnational campaigns raise relations with the mainland as an issue. Therefore, we have decided to use Taiwan presidents' magnitude or intensity on cross-strait relations as a measure of their diversionary behavior.

Nevertheless, no existing dataset has defined a measurement for Taiwan PIUM. Nor has existing research used PIUM as a quantitative variable. We code this variable from scratch through Taiwan's Central News Agency. ${ }^{12}$ The Central News Agency is the official Englishlanguage news agency in Taiwan. By searching keywords in the LexisNexis system, ${ }^{13}$ all news articles that contain contents related to Taiwan independence or unification, from January 1, 1995, to March 20, 2004, were gathered. At this stage, we are concerned only about official positions of different presidents and their respective parties on the issue of Taiwan independence or unification; therefore, unofficial rhetoric is dropped. Four major parties are included. The DPP is coded as the proindependence party. The KMT and the People First Party (PFP)—the Pan-Blue ${ }^{14}$ coalition - plus the New Party (NP) are coded as the prounification coalitions.

Data are gathered on a daily basis. Each remark regarding a particular party's position on Taiwan independence or unification is measured for its pro-independence (negative 1) or pro-unification (positive 
1) stance (see Table 1) and its intensity (low, medium, and high; 1, 2, and

3) (see Table 2). For example, KMT chair Lien Chan lashed out, on March 16, 2001, at the DPP government for making the country "grope in the dark" with no goal in its mainland China policy, stressing that the Guidelines for National Unification and the "92 Consensus" are the best policies to stabilize and improve Taiwan's relations with mainland China. This is a clear statement in favor of an eventual unification with the mainland. The remark is coded as a high-intensity pro-unification comment (i.e., 1 [pro-unification] x 3 [high-intensity] = 3). By the same token, President Chen Shui-bian said during an interview with Harvey Sicherman on January 21, 2003, that "the Republic of China (ROC) is a sovereign state. This is the clear and obvious status of our country. The ROC effectively exercised jurisdiction over the islands of Taiwan, Penghu, Kinmen, and Matsu - a fact no one can deny." This is a clear statement saying from the highest level of the DPP government that Taiwan is a sovereign state. Therefore, it is coded as -1 (pro-independence) $x 3$ (highintensity) $=-3$ (see Table 3 for examples). Thus, higher positive values of the PIUM indicate more intense, pro-unification rhetoric, while negative values indicate pro-independence rhetoric. The PIUM variable then is aggregated by month. ${ }^{15}$ Figure 1 displays the PIUM over time.

A one-month lag is created to capture changes over time. To control for which party holds the presidency, we create a Party Identification dummy variable, where KMT is assigned the value 0 and DPP 1 . To test the opposition's influence on Taiwan's presidential approval, we also create an Opposition Magnitude variable. The Opposition Magni-

Table 1 Pro-independence vs. Pro-unification

\begin{tabular}{lc}
\hline \multicolumn{1}{c}{ Type } & Value \\
\hline Pro-independence & -1 \\
Mutual & 0 \\
Pro-unification & 1 \\
\hline
\end{tabular}

\section{Table 2 Rhetoric Intensity}

\begin{tabular}{lc}
\hline Type & Value \\
\hline Mutual & 0 \\
Low & 1 \\
Medium & 2 \\
High & 3 \\
\hline
\end{tabular}


Table 3 Examples of the President's Independence or Unification Magnitude (Media Source: Central News Agency)

\begin{tabular}{|c|c|c|c|}
\hline Date & Rhetoric & Value & Justification \\
\hline $3 / 16 / 01$ & $\begin{array}{l}\text { Kuomintang Chairman Lien Chan } \\
\text { lashed out Friday at the current } \\
\text { government led by the Democratic } \\
\text { Progressive Party (DPP) for making } \\
\text { the country "grope in the dark" with } \\
\text { no goal in its mainland China policy. } \\
\text { Stressing that the Guidelines for } \\
\text { National Unification and the "92 } \\
\text { Consensus" are the best policies to } \\
\text { stabilize and improve Taiwan's } \\
\text { relations with mainland China, Lien } \\
\text { accused the present DPP government } \\
\text { of dumping the guidelines and instead } \\
\text { putting forward the empty slogan of } \\
\text { "integration theory." }\end{array}$ & 3 & $\begin{array}{l}\text { Pro-unification; clear intention } \\
\text { to go back to the "92 } \\
\text { consensus" and defend the } \\
\text { unification guidelines. }\end{array}$ \\
\hline $1 / 21 / 03$ & $\begin{array}{l}\text { President Chen Shui-bian said } \\
\text { during an interview with Harvey } \\
\text { Sicherman that "the Republic of } \\
\text { China (ROC) is a sovereign state. } \\
\text { This is the clear and obvious status } \\
\text { of our country. The ROC effectively } \\
\text { exercised jurisdiction over the islands } \\
\text { of Taiwan, Penghu, Kinmen, and } \\
\text { Matsu-a fact no one can deny." }\end{array}$ & -3 & $\begin{array}{l}\text { Pro-independence; clear } \\
\text { articulation of the position that } \\
\text { Taiwan is a sovereign state. }\end{array}$ \\
\hline $2 / 3 / 04$ & $\begin{array}{l}\text { President Chen Shui-bian said } \\
\text { Tuesday that if he is reelected in } \\
\text { March, he will continue to honor } \\
\text { his "four noes plus one" pledge and } \\
\text { safeguard Taiwan's present status } \\
\text { quo, including its sovereign status } \\
\text { and peace with mainland China. }\end{array}$ & -1 & $\begin{array}{l}\text { Pro-independence in general; } \\
\text { clear intention to maintain } \\
\text { sovereign status. }\end{array}$ \\
\hline $3 / 8 / 04$ & $\begin{array}{l}\text { Lien, who is the sole challenger } \\
\text { of President Chen Shui-bian in } \\
\text { Taiwan's March } 20 \text { presidential } \\
\text { election, noted that the Republic } \\
\text { of China has been in existence } \\
\text { for } 93 \text { years and said that his "pan- } \\
\text { blue alliance" of the opposition } \\
\text { Kuomintang and its ally the People } \\
\text { First Party, opposes Taiwan } \\
\text { independence. }\end{array}$ & 2 & $\begin{array}{l}\text { Pro-unification in general; no } \\
\text { clear statement about } \\
\text { unification with China, but } \\
\text { clearly opposes Taiwan } \\
\text { independence. }\end{array}$ \\
\hline
\end{tabular}

tude variable is coded opposite to the PIUM variable. To be more precise, when the PIUM variable has a negative value (meaning proindependence), the Opposition Magnitude is scored the opposite (a negative value indicating pro-unification). The Opposition Magnitude variable also is aggregated by month and lagged by one time unit. 
Figure 1 Presidential Independence Magnitude Over Time

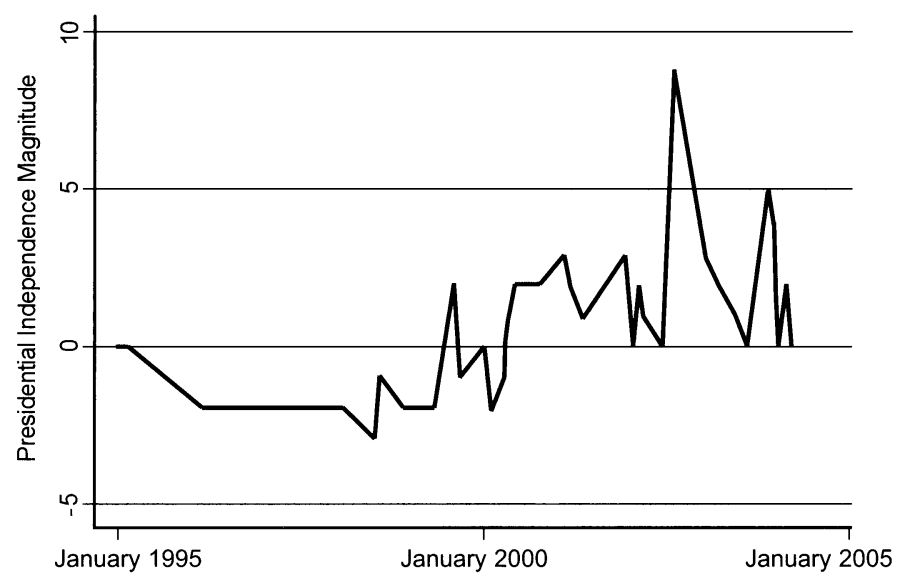

In this article, we suggest that Taiwan's president will use independence to divert attention from domestic problems. In turn, proindependence rhetoric certainly will affect the presidential approval rating. Presidential approval data are collected from several different sources on a daily, quarterly, or yearly basis; this variable is aggregated by month. ${ }^{16} \mathrm{~A}$ lagged presidential approval rating is created.

Several independent variables are used to measure Taiwan's domestic politics and linkage politics. As a measurement for domestic economic performance, the so-called misery index has been widely used in previous studies on DT (James and Oneal 1991). Other scholars, such as Fordham (1998a, 1998b) and DeRouen (2000), used inflation and unemployment separately as indicators for domestic economic performance. We adopt the latter approach to give us a more detailed analysis of the domestic economic impact. Inflation rate and unemployment rate variables are collected monthly. A one-time unit lag also is created.

Despite tensions between China and Taiwan in high politics, there is a strong and ever growing linkage in low politics across the Taiwan Strait. Over the past few decades, investments from Taiwan have poured into mainland China. Due to Taiwan's economic difficultiesmost notably high inflation and unemployment rates in recent yearsmainland China even managed to attract many members of Taiwan's labor force. Since the establishment of the "Mini Three Links"17 in 2001, exchanges between China and Taiwan further increased. 
Given the close linkage at the low politics level, it is appropriate to include several variables to account for this effect. First, trade between China and Taiwan is included in the model. This variable includes trade (imports plus exports) across the Taiwan Strait. Appendix 1 shows the general upward trend of cross-strait trade between 1984 and 2008. Second, since the 1980s, both China and Taiwan have allowed Taiwanese to visit mainland China. Over the years, the number of visits from Taiwan to China has increased dramatically. Exchanges of people have contributed to building a stronger linkage at the low-politics level. Thus, it is also proper to include exchange of people as a control variable in the model. Appendix 2 shows the more dramatic upward trend in cross-strait visits between 1993 and 2007.

We expect the proximity to a presidential election will affect either the president's use of pro-independence (or pro-unification) rhetoric or his presidential approval rating. For example, when an election nears, the incumbent and the opposition candidates might be expected to move to the median voter position to gather more votes. Such action might subsequently influence the candidates' respective rhetorical positions on independence and unification. To control for this effect, we include an Election Proximity variable in the model. The closer it gets to the presidential election, the smaller the value is for the election proximity variable. Finally, we include Taiwan's per capita GDP as a standard control variable.

\section{Time Frame of the Data Analysis}

The year 2000 marks Taiwan's second direct presidential election. The 2000 election also marks the first time a non-KMT party candidateChen Shui-bian of the DPP-won a presidential election. ${ }^{18}$ Prior to the first direct presidential election in 1996, leaders had been appointed by their KMT predecessors. Lee Teng-hui became president in 1988 under the old system, but his running as the incumbent (and winning as the first directly elected president) constitutes a significant change from the past. Lee gradually began actively promoting pragmatic diplomacy for Taiwan and advocating Taiwan independence, at least implicitly. As noted previously, his gradual shift to a more pro-independence stance (Hickey 2007) led China to conduct live missile tests in the Taiwan Strait in 1995 and 1996. To account for the gradual transition from the KMT rule to the DPP rule, it would be reasonable to include Lee Tenghui's last term in this research as well-thus the data span January 1995-March 2004. 


\section{Statistical Procedure}

As previously discussed, we postulate two dependent variables: Presidential Approval and Independence Magnitude. We also argue that these are co-causal or have reciprocal causation in the following fashion: as the president's approval sinks, the likelihood of his raising the issue of independence increases; as the president discusses independence, his approval is expected to rise. While this design may appear to be a simultaneous model, it is not because of the lag in learning between the president and public. The president must learn what his approval rating is before he can react to it, and the public must hear or read the president's independence rhetoric before it can affect their opinion of him.

Fortunately, the time series data permit us to model this co-causal process. While the two variables are clearly not simultaneous, they are linked through their error terms. Therefore, we use the Seemingly Unrelated Regression (SUR) estimator. ${ }^{19}$

\section{Data Analysis}

Because there is a high level of multicollinearity between the number of visits and trade on the one hand, and inflation and unemployment on the other, we separate the models into two different estimations. The results appear in Tables 4 and 5. Equation 1 in both tables tests the respective independent variables' influence on the magnitude of the president's independence rhetoric. The main variable, Lagged Presidential Approval, which tests the Diversionary hypothesis, reaches statistical significance in both estimations. The coefficients are -8.12 and -6.79 in Tables 4 and 5 , respectively. The statistical significance of the variable shows strong support for the Diversionary hypothesis-namely, as the president's approval sinks, he is more likely to engage in pro-independence rhetoric.

Empirically speaking, this is particularly true for the DPP president Chen Shui-bian. Between the 2000 and 2004 elections, Chen's low approval rating was often coupled with his increasingly pro-independence remarks. Prior to the March 2004 election, for example, Chen had gradually introduced measures that led to the 2004 referendum, which, if passed, would have paved the way for a potential mechanism leading to a formal declaration of independence in the future. Creation of the referendum issue, successful or not, effectively allowed Chen Shuibian to divert attention from his low approval rating to the issue of independence. Similarly, Lee Teng-hui's "special state-to-state" relations 


\section{Table 4 Seemingly Unrelated Regression Analysis of Promotion of Taiwanese Independence and Presidential Approval (Inflation and Unemployment)}

\begin{tabular}{lccc}
\hline Equation & Observations & R-Squared & \\
\hline President's Independence Magnitude & 92 & 0.688 & \\
Presidential Approval & 92 & 0.846 & \\
& Coefficient & Standard Error & P-Value \\
& & & \\
\hline Equation 1: President's Independence & & & \\
Magnitude & -8.122864 & 2.882 & 0.005 \\
Lagged Presidential Approval & -0.2583529 & 0.156 & 0.097 \\
Lagged Inflation & 0.1249128 & 0.306 & 0.683 \\
Lagged Unemployment & 1.75186 & 0.903 & 0.052 \\
Party Identification dummy & 0.001801 & 0.001 & 0.055 \\
GDP per capita & 0.0055861 & 0.015 & 0.718 \\
Election Proximity & -3.367335 & 3.660 & 0.358 \\
Constant & & & \\
& & & \\
Equation 2: Presidential Approval & -0.0040453 & 0.003 & 0.207 \\
Lagged President's Independence & & & \\
$\quad$ Magnitude & 0.0233411 & 0.004 & 0.000 \\
Lagged Opposition Magnitude & -0.014094 & 0.004 & 0.001 \\
Lagged Inflation & 0.0083223 & 0.009 & 0.364 \\
Lagged Unemployment & -0.1046735 & 0.029 & 0.000 \\
Party Identification dummy & 0.0000575 & 0.000 & 0.042 \\
GDP per capita & 0.0026596 & 0.000 & 0.000 \\
Election Proximity & 0.2265284 & 0.107 & 0.035 \\
Constant & & & \\
\hline
\end{tabular}

remarks and his Cornell visit also effectively stimulated a diversion away from other domestic problems and toward cross-strait relations.

The results do not support the Misery hypothesis, which asserts that a weak economy or high unemployment rate will spur the president to discuss independence in a positive light. The lack of significance of the inflation and unemployment variables shows that the president is not using domestic economic problems as a reason to engage in diversionary behaviors toward mainland China. Blaming an economic downturn on China potentially would enhance the argument that Taiwan depends on the mainland for its economic development, consequently weakening the president's advocacy of a more independent Taiwan. In light of Fordham's (1998a, 1998b) assessment of unemployment (not inflation) as a likely stimulant for the use of force, with support from the data in the US context, it becomes interesting to see what economic aspect(s) might emerge as important for Taiwan. If there is an economic story to be told, it obviously concerns something other than inflation or unemployment. 


\section{Table 5 Seemingly Unrelated Regression Analysis of Promotion of Taiwanese Independence and Presidential Approval (Visits and Trade)}

\begin{tabular}{lccc}
\hline Equation & Observations & R-Squared & \\
\hline President's Independence Magnitude & 92 & 0.691 & \\
Presidential Approval & 92 & 0.838 & \\
& Coefficient & Standard Error & P-Value \\
\hline Equation 1: President's Independence & & & \\
Magnitude & & & \\
$\quad$ Lagged Presidential Approval & -6.794687 & 2.552 & 0.008 \\
Lagged Visit & 0.0000267 & 0.000 & 0.045 \\
Lagged Trade & 0.0004873 & 0.001 & 0.335 \\
Party Identification dummy & 1.659298 & 0.980 & 0.090 \\
GDP per capita & 0.001841 & 0.001 & 0.030 \\
Election Proximity & -0.0045836 & 0.014 & 0.747 \\
Constant & -5.64759 & 2.724 & 0.038 \\
& & & \\
Equation 2: Presidential Approval & & & \\
Lagged President's Independence & -0.0031916 & 0.003 & 0.332 \\
$\quad$ Magnitude & & & \\
Lagged Opposition Magnitude & 0.0290315 & 0.004 & 0.000 \\
Lagged Visit & 0.00000119 & 0.000 & 0.002 \\
Lagged Trade & 0.00000995 & 0.000 & 0.538 \\
Party Identification dummy & -0.0749001 & 0.033 & 0.023 \\
GDP per capita & 0.0000632 & 0.000 & 0.015 \\
Election Proximity & 0.002077 & 0.000 & 0.000 \\
Constant & 0.1645142 & 0.089 & 0.065 \\
\hline
\end{tabular}

The results also partially contradict the Cordial Relations hypothesis. First, the trade variable does not reach statistical significance. Second, the cross-strait visit variable does reach statistical significance-but not in the expected direction. These results may be caused by one or more of the reasons that follow. By independently examining trade and crossstrait visits data, we see that cross-strait trade and visits have been rising steadily over the last several decades. While Taiwan continues to democratize and develop its new identity, its economic dependence on mainland China has become more substantial. The issue of independence versus unification is largely a political issue. Therefore, the low politics issues - trade and visits - have become relatively independent of the independence-unification issue. Regardless of the future political status of Taiwan, low politics exchanges will go on across the Taiwan Strait.

Note that the GDP per capita control variable reaches statistical significance in both models, indicating that as the overall economy is getting better, leaders in Taiwan have increasingly greater leverage to promote a more independent Taiwan identity. This result, when com- 
bined with the impact of approval, creates an interesting twist. The situation most disposed toward diversionary rhetoric is one that sees a relatively unpopular leader presiding over a more, not less, prosperous Taiwan. It would not go too far to describe the situation as worrisome: If popularity does not come with economic success in the general sense of a higher income per capita, it is likely to be pursued by other means, with rhetoric as a provocative and potentially dangerous option.

Overall, while some hypotheses fare better than others, the model performs reasonably well, with $\mathrm{R}^{2}=0.69$ in each instance. The control variable for the president's party is significant, indicating that the DPP tends to be more pro-independence than the KMT. ${ }^{20}$ This effect is expected, since the DPP tends toward independence and the KMT is strongly against it. The variable's impact is very strong, also not surprising, as the two parties define themselves partly along these lines and their respective politicians would hold views appropriate to their party. What is particularly important to highlight is that even with this significant, strong effect, our theoretical variables are not overpowered by the party control variable.

The Election Proximity variable does not reach statistical significance. It is consistent with the conventional knowledge that when the real election nears, both DPP and KMT tend to tone down their message to move toward the median voter position. In general, we find the results encouraging for the Diversionary hypothesis in an overall, political sense.

Equation 2 in Tables 4 and 5 models the president's approval rating. First, we find a result that contradicts the Independence hypothesis: as the president increases his pro-independence rhetoric, his approval decreases - the opposite of a rally effect. The Lagged Presidential Independence or Unification Magnitude variable does not reach statistical significance in either Table 4 or Table 5.

The more the opposition party uses pro-unification rhetoric, the more the public disapproves of the president, which confirms our Opposition hypothesis. It seems that Taipei's executive is better served when the opposition holds a pro-unification position. Thus, there is a balancing effect between the president and his opposition that can nullify or even reverse the negative impact independence has on approval.

We are able to partially confirm the Economy hypothesis. The inflation variable reaches statistical significance in the expected direction. Higher inflation in Taiwan tends to hurt the president's approval rating. However, the model does not provide evidence that a high unemployment rate will have the same impact. This is a fascinating result, especially given that the inflation variable reaches significance while unem- 
ployment does not. The nonfinding about unemployment in relation to executive standing with the public is at odds with the connections usually found in other states (i.e., "pocketbook voting"). To the extent that inflation influences foreign policy decisions-and unemployment might not - the data suggest that this different dynamic warrants further study as the DT agenda expands to include new forms of foreign policy behavior, middle powers, and possibly other features.

As regards the control variables, the number of visits and the level of cross-strait trade do affect the approval rating with some marginal effect. This result may be caused by one or more of the following. First, more visits are associated with an increase in the public's opinion of the chief executive. This effect is small-a one standard deviation increase in the number of visits equals an increase of 1.5 percent in approvalbut significant. Second, cross-strait visits could bring more substantial impact than trade on the public. As more people travel to the mainland to see it with their own eyes, they are likely to give more positive marks for what the president is doing. Trade is important, but it is not nearly as visible to the citizenry as visits. Also, as the overall economic condition improves, presidential approval increases. Finally, as the election nears, the president also gets a higher approval rating. This finding is consistent with the lack of significance for the Election Proximity variable in equation 1 . As an election nears, the president becomes less aggressive in his remarks regarding the issue of independence/unification. He tends to move toward the center of the continuum, hoping to obtain a higher approval rating. The $\mathrm{R}^{2}$ for equation 2 is 0.84 for both estimations.

\section{Conclusions and Implications}

Testing has yielded some interesting findings and implications. Data analysis confirms the two main hypotheses: Diversionary and Opposition. With regard to diversionary theory in general, our findings provide significant support for such behavior in the Taiwan Strait. In a more general sense, this encourages further breadth of application for at least the diversionary components of the present model; it should be adapted to other contexts-most notably, additional middle powersand subjected to testing there. Moreover, diversionary behavior should not be understood only in a limited, military sense. Nonmilitary diversionary behavior can be used, as it appears, by foreign policy decisionmakers to achieve diversionary effects.

Results obtained in this study also add depth to DT by showing the theory's effectiveness in an especially challenging case. Leaders in Tai- 
wan do seem to use their positions on Taiwan independence to divert attention from their domestic problems. (It is interesting to pause here and note that "problems" do not seem to include some of the usual economic indicators-namely, high unemployment and inflation.) Whether pro-unification or pro-independence, the lower the president's approval, the more he promotes Taiwan independence. ${ }^{21}$ This finding also suggests several Taiwan-China-specific implications.

First, most people in Taiwan are not opposed to a more independent or unique Taiwan identity. ${ }^{22}$ When leaders are promoting such an identity, people tend to offer some level of support. However, the discussion of Taiwan independence seems to become intense only around election years. The topic has increasingly become a campaign tool for both the KMT and DPP. Leaders from both parties know an immediate declaration of independence or unification will hurt Taiwan's interests. A quick settlement of the Taiwan issue is less likely. Therefore, both parties are using Taiwan independence or unification to keep from losing votes. Both parties try to place themselves at the median voter position in order to win elections. An implication for mainland China and the United States is that they should be aware of the fact that most people in Taiwan are willing to endorse a more independent identity. Thus, policies toward Taiwan should become more flexible than before. Prior policies may not reflect the changing nature of the Taiwan issue. Both China and the United States should adjust their positions accordingly.

Second, the more democratic Taiwan becomes, the greater say its public will have in the unification/independence debate. Decisions on cross-strait relations may no longer be fully controlled by the Taiwan government because the public has increasingly demanded a more important role in the decisionmaking process. The use of independence as a diversion may result in leaders losing their effectively oligarchical control of the issue.

Third, because Taiwan independence or unification has become a bipartisan issue and to some extent a mere campaign tool to win elections, parties have incorporated it into the strategic landscape. Neither party seems sincere about resolving this long-lasting issue. Both parties have clear divisions on this matter. To avoid further escalation, bipartisan cooperation may be conducive to resolving the ongoing Taiwan crisis.

Finally, both China and the United States should avoid getting involved in issues related to Taiwan's elections. Chinese and US involvement can only complicate matters. Fortunately, so far both China and the United States have restrained themselves. Nevertheless, China and the United States should not signal a lack of interest in resolving 
the Taiwan issue. Cooperation between and among the various sides may be essential to a final resolution of the Taiwan issue.

Any treatment of the complex processes of interaction in the Taiwan Strait will exhibit limitations, and this study is no different. Several directions for further research appear salient in light of the results. First, the model as specified does not include actions by the other two key players: China and the United States (Chan 2003; James and Zhang 2005; Zhang 2008). A variable focusing on Chinese actions toward Taiwan, which could help to explain PIUM in the next time interval, may be the most obvious omission. Elaboration of the model, however, must await additional data collection. This will require further concept formation and operationalization of relevant variables. Adding such variables, moreover, will become feasible when the most recent data become available.

Second, the study at present does not focus on institutional variables. What about the role of East Asian institutions in the political processes of the region? While the China-Taiwan dyad features its own dynamics, institution building in East Asia also is worthy of attention (Narine 2008). Variables focusing on the role of institutions such as APEC might be conceptualized, measured, and integrated in a more comprehensive model.

Third, and foreshadowed in various discussions already, is the need to go beyond the era covered by the present analysis. Significant developments in Taiwan and China may have had an impact on the connections revealed here. In early 2008, the KMT defeated the DPP in a landslide election. KMT president-elect Ma Ying-jeou assumed office on May 20. It is largely believed that Ma will be more cooperative in dealing with the mainland government to ensure a peaceful relationship in the Taiwan Strait. He has long argued in favor of returning to the 1992 Consensus, allowing more mainland visitors to visit Taiwan, starting direct flights between Taiwan and the mainland, and further facilitating trade with and investments in China, just to name a few examples. Furthermore, Chen Shui-bian's rigid rules on investing in mainland China caused some economic problems in the recent past. For example, the Chen government placed a 40 percent cap on each Taiwanese company's investment in China (Lynch 2006; Kang 2007). Certain industries, such as high-tech computer silicon chip production lines, were not allowed to move to the more cost-effective mainland market at all. These restrictions severely limited Taiwan's economic growth. Voters in Taiwan expect Ma to lead Taiwan out of the economic downturn. And mainland China's vast economic market seems to be the most apparent and convenient solution for Taiwan.

Since Ma took office, he has sent several top Taiwanese officials to the mainland to improve relations. On December 15, 2008, the main- 
land and Taiwan finally ended the fifty-nine-year-long ban on direct air and sea transport and postal services, establishing the long-overdue direct "Three Links" - a major sign of improved relations. Taiwan also warmly received the pair of pandas-Tuantuan and Yuanyuan (meaning "reunion" when the two names are combined)—gifted by Beijing. It must be noted however, to please the popular demand of Taiwanese citizens, President Ma has called explicitly for the "principle of no unification, no independence and no use of force" and the upholding of Taiwan's democracy. Polls show that Ma's popularity rating dropped from 41 percent one month after the election to roughly 30 percent one year after he took office-bouncing back from his lowest rating of 23 percent due to a tainted milk scandal four months into his presidency. It appears that Ma's top priority right now is to continue improving cross-strait relations while maintaining the status quo.

Due to limitations on data collection, the analysis in this current project only focused on the time period 1995-2004. Both presidents Lee Teng-hui and Chen Shui-bian exhibited pro-independence behaviors to a varying degree. Taiwan is now under the pro-unification leadership of Ma Ying-jeou. Furthermore, evidence suggests that an immediate and clear declaration of independence is no longer favored by Taiwanese as a viable option. The strong surge of a separate "Taiwan identity" movement in the 1990s, promoted by the DPP, has not solved problems effectively (Ross 2006). It is clear, however, that an immediate unification with mainland China is not a likely option either. We will begin data collection soon to extend our time period to include the current KMT administration. To us, if maintaining the status quo is the best strategy for the government in Taipei, pro-unification rhetoric could be just as effective and/or practical as pro-independence remarks as a form of tactical and political diversion if Taiwanese leaders are in trouble at home. To be more specific, Taiwanese voters might be distracted by a "peace offensive" initiated by their leader. Taiwanese leaders also could use improved relations with Beijing to induce voters to reward politicians with higher approval ratings.

Finally, this study attempts to expand current thinking about DT as well as the challenging relationship in the Taiwan Strait. It is hoped that further research efforts in both those areas will be encouraged by what has been discovered here.

Yitan Li is assistant professor of political science at Seattle University. His research focuses on international relations, foreign policy analysis, international conflict and security, international political economy, comparative politics, and Chinese and East Asian politics. He has published recently in Asian Affairs, 
Canadian Journal of Political Science, Foreign Policy Analysis, International Studies Perspectives, Nationalism and Ethnic Politics, and Political Research Quarterly.

Patrick James is professor of international relations and director of the Center for International Studies at the University of Southern California. He is the author or editor of twelve books and over one hundred other academic publications. James will be honored as the Distinguished Scholar in Ethnicity, Nationalism, and Migration by the International Studies Association at its annual meeting in 2010.

A. Cooper Drury is associate professor of political science at the University of Missouri and editor-in-chief of Foreign Policy Analysis. His research and teaching focus broadly on foreign policy and international political economy. He has published extensively on the use and consequences of economic sanctions.

\section{Appendix 1 The Share of Cross-Strait Trade in Taiwan, Total Foreign Trade Estimates by Mainland Affairs Council, ROC}

\begin{tabular}{lccc}
\hline & \multicolumn{3}{c}{ Unit: $\%$} \\
\cline { 2 - 4 } Year & Export Share & Import Share & Total Trade Share \\
\hline 1984 & 1.4 & 0.58 & 1.06 \\
1985 & 3.21 & 0.58 & 2.17 \\
1986 & 2.04 & 0.6 & 1.49 \\
1987 & 2.28 & 0.83 & 1.71 \\
1988 & 3.7 & 0.96 & 2.47 \\
1989 & 5.03 & 1.12 & 3.31 \\
1990 & 6.54 & 1.4 & 4.23 \\
1991 & 9.79 & 0.46 & 5.57 \\
1992 & 12.84 & 1.03 & 7.31 \\
1993 & 16.28 & 1.31 & 9.19 \\
1994 & 16.99 & 2.17 & 9.93 \\
1995 & 17.15 & 2.97 & 10.36 \\
1996 & 17.63 & 2.97 & 10.79 \\
1997 & 18.08 & 3.41 & 11.03 \\
1998 & 17.62 & 3.91 & 11 \\
1999 & 17.22 & 4.07 & 10.67 \\
2000 & 16.46 & 4.43 & 13.45 \\
2001 & 20.27 & 5.47 & 15.89 \\
2002 & 23.3 & 7.04 & 17.7 \\
2003 & 25.43 & 8.61 & 18.72 \\
2004 & 26.83 & 9.95 & 20.04 \\
2005 & 28.36 & 11 & 20.65 \\
2006 & 28.27 & 12.23 & 21.95 \\
2007 & 30.11 & 12.77 & 22.22 \\
Jan-08 & 30.42 & 13.41 & \\
\hline
\end{tabular}

Sources: Hong Kong Customs Statistics; ROC Customs Statistics; www.mac.gov.tw/big5/ statistic/em/182/8.pdf. 
Appendix 2 Visits Across the Taiwan Strait

\begin{tabular}{|c|c|c|c|c|c|c|}
\hline \multirow[b]{2}{*}{ Year } & \multicolumn{3}{|c|}{ Taiwan Vistors to Mainland } & \multicolumn{3}{|c|}{ Mainland Visitors to Taiwan } \\
\hline & Persons & $\begin{array}{l}\text { Year-to-Year } \\
\text { Growth }(\%)\end{array}$ & Cumulation & Persons & $\begin{array}{l}\text { Year-to-Year } \\
\text { Growth }(\%)\end{array}$ & Cumulation \\
\hline 1993 & $1,526,969$ & - & $5,726,350$ & 18,445 & 39.98 & 37,080 \\
\hline 1994 & $1,390,215$ & -8.96 & $7,116,565$ & 23,654 & 28.24 & 60,734 \\
\hline 1995 & $1,532,309$ & 10.22 & $8,648,874$ & 42,295 & 78.81 & 103,029 \\
\hline 1996 & $1,733,897$ & 13.16 & $10,382,771$ & 56,545 & 33.69 & 159,574 \\
\hline 1997 & $2,117,576$ & 22.13 & $12,500,347$ & 73,848 & 30.6 & 233,422 \\
\hline 1998 & $2,174,602$ & 2.69 & $14,674,949$ & 90,387 & 22.4 & 323,809 \\
\hline 1999 & $2,584,648$ & 18.86 & $17,259,597$ & 106,254 & 17.55 & 430,063 \\
\hline 2000 & $3,108,643$ & 20.27 & $20,368,240$ & 116,311 & 9.47 & 546,374 \\
\hline 2001 & $3,441,961$ & 10.72 & $23,810,201$ & 133,988 & 15.2 & 680,362 \\
\hline 2002 & $3,660,565$ & 6.35 & $27,470,766$ & 154,770 & 15.51 & 835,132 \\
\hline 2003 & $2,731,897$ & -25.37 & $30,202,663$ & 134,811 & -12.9 & 969,943 \\
\hline 2004 & $3,685,250$ & 34.9 & $33,887,913$ & 138,561 & 3.36 & $1,108,504$ \\
\hline 2005 & $4,109,187$ & 11.5 & $37,997,100$ & 172,982 & 24.14 & $1,281,486$ \\
\hline 2006 & $4,413,470$ & 7.4 & $42,410,570$ & 243,185 & 40.58 & $1,524,671$ \\
\hline 2007 & $4,627,881$ & 4.86 & $47,038,451$ & 320,169 & 31.66 & $1,844,840$ \\
\hline
\end{tabular}

Sources: China Monthly Statistics and China Travel Yearbook, PRC. www.mac.gov.tw/ big5/statistic/em/182/19.pdf. National Immigration Agency, Ministry of the Interior of Taiwan, ROC. www.mac.gov.tw/big5/statistic/em/182/20.pdf.

\section{Notes}

We would like to thank the editor and the two anonymous reviewers for their very constructive comments.

1. An insightful account of the evolving US foreign policy toward China from the Nixon era onward, with an emphasis on strategic engagement, appears in Garrison (2005).

2. Fordham (2005), for example, produces an extremely insightful account of how "strategic conflict avoidance" could affect the degree of confirmation achieved by DT as a result of states being especially careful not to confront the United States when it is going through domestic difficulties that might create a disposition toward diversion. This result is not regarded as applicable to the context of Taiwan's relations with the PRC because it is inconceivable that the PRC would experience the same reluctance to upset Taiwan regardless of the latter's internal state of affairs. This example serves as a reminder that only some of the previous DT literature can inform the present study, which focuses on a middle, not a great, power.

3. Between May 19, 1949, and July 15, 1987, Taiwan was under martial law, due to its fear of invasion by the PRC and its self-stated readiness to attack and recover all of China at any time.

4. As part of Lee Teng-hui's pragmatic diplomacy, a June 1995 visit to Cornell University as an alumnus sparked a series of protests from China. The 
PRC reacted strongly to Lee's pragmatic move, accusing him of having "split the motherland."

5. He made this remark on July 9, 1999.

6. China's military exercise did not prevent Lee Teng-hui from being elected president.

7. Chen proclaimed that as long as the PRC did not use military force against Taiwan, he would not declare Taiwan independent of China; he would not support changing the national title of the Republic of China; he would not push for the inclusion of Lee Teng-hui's "state-to-state" description in the ROC constitution; he would not promote an island-wide referendum on the island's status, and he would not abolish the National Reunification Council or the National Reunification Guidelines (see Hickey and Li 2002 for a detailed discussion).

8. We do not challenge the importance of the subtle difference between Taiwan independence and a greater degree of autonomy. Instead, we argue that it is precisely the subtle difference that Taiwanese leaders take advantage of in their rhetoric. They know a quiet pursuit of more autonomy might be regarded as the equivalent of a more independent status. Taiwan's relations with mainland China have become a political issue that can be used for strategic purposes. Therefore, when they are in trouble at home, they have the motivation to use their positions on cross-strait relations as a political and strategic tool to divert attention from domestic problems.

9. We would like to point out that the proposed diversionary strategy was used by both Lee Teng-hui and Chen Shui-bian. As it will become apparent when we discuss our main dependent variable - the President's Independence or Unification Magnitude - in the next section, the Diversionary hypothesis is not necessarily partisan-based in Lee's case. Although Lee promoted Taiwan independence toward the end of his administration as a KMT member, we do not expect other KMT leaders, such as the current president, Ma Ying-jeou, to promote Taiwan independence.

10. Two types of risks constrain policymakers when making foreign policy decisions-policy risk and political risk. Policy risk is "the probability that the substantive goals of established policy will not be achieved." Political risk is "the probability that policy choices will have adverse effects on the political position of the policy-making factions" (Lamborn 1991, 5). For example, Lee Teng-hui's "special state-to-state" remarks and his private visit to the United States in 1995 angered Beijing. Beijing subsequently ended the cross-strait dialogues that started in the early 1990s. The ending of the cross-strait dialogues posed a policy risk to Taiwan as effective communications were cut. In addition, the KMT was also perceived as not being able to maintain the only semiofficial communication across the Taiwan Strait. KMT's political risk also increased due to the failure to maintain those dialogues.

11. In March 2004, the Taiwanese voted on a referendum that potentially could allow Taiwan to acquire more defensive weapons. Although voters who had cast votes on the referendum voted overwhelmingly in favor of it, the overall turnout of 45.1 percent did not exceed the 50 percent of registered voters required to validate the referendum. There were two questions on the referen- 
dum. The first question was: "The People of Taiwan demand that the Taiwan Strait issue be resolved through peaceful means. Should Mainland China refuse to withdraw the missiles it has targeted at Taiwan and to openly renounce the use of force against us, would you agree that the Government should acquire more advanced anti-missile weapons to strengthen Taiwan's self-defense capabilities?" The second question was: "Would you agree that our Government should engage in negotiation with Mainland China on the establishment of a 'peace and stability' framework for cross-strait interactions in order to build consensus and for the welfare of the peoples on both sides?" Mainland China and the United States also feared that a successful referendum might set a precedent for using referenda as a tool by the Taiwanese to decide the political fate of their future.

12. We realize that newspapers in Taiwan vary in their positions regarding the issue of unification and independence. It is particularly true for newspapers published in Chinese. At this initial stage, we use Central News Agency's English-language version as a presumably neutral source. Further investigation into news sources in Chinese will be conducted later.

13. Through the LexisNexis system, we used keywords such as China, Taiwan, unification, independence, president, or election to obtain 325 pages of newspaper articles from Taiwan's Central News Agency.

14. There are two major political coalitions in Taiwan. The Pan-Blue represents the pro-unification coalition led by the KMT. The Pan-Geen represents the pro-independence coalition led by the DPP.

15. The unit of analysis of the PIUM variable is daily events. To be more precise, each remark is treated as one data point. On any given day, multiple remarks may be made regarding Taiwan's relations with mainland China. Moreover, the common overlapping unit of analysis for other variables is monthly data. We collapsed (aggregated) the daily data into monthly data by taking the running average of the PIUM variable.

16. During a nonelection year, presidential rating is available on a quarterly or yearly basis. During an election year, presidential rating is available on a daily basis as the election approaches.

17. In 1979, China proposed the Three Links: direct transportation, postal services, and trade, and Four Exchanges: academic, cultural, sports, and technological exchange proposals to promote cross-strait exchanges. Taiwan had opposed any exchanges across the Taiwan Strait, fearing that further exchanges would make Taiwan more dependent on China. All personnel, trade, and postal transportations had to go through a third port, such as Hong Kong or Japan. In 2001, under pressure from the business community, Taiwan authorized direct traffic between Taiwan and the mainland; however, the traffic was only between the two Taiwan-controlled islands and the two port cities on the mainland. Therefore, the link is referred as the "Mini Three Links." After the Mini Three Links, Beijing and Taipei allowed direct flights during Chinese Lunar New Year. Full-scale Three Links were not restored until December 15, 2008.

18. Taiwan had been under KMT rule since the KMT fled from mainland China to Taiwan after losing the civil war. 
19. More specifically, the error terms in the two equations (Presidential Approval and PIUM) are correlated with each other, making the error variance covariance matrix non-diagonal. As Meernik (2000) points out in a similar study, by treating the two equations as one large, combined equation, SUR estimation efficiently corrects this problem (see also Kmenta 1986, 635, 636; Pindyck and Rubinfeld 1981,333). Therefore, we estimate both models as part of a SUR equation system.

20. Party ID is weakly significant in Table 5.

21. As we conclude the initial research for the 1995-2004 period, we are beginning to collect data for the 2008 election, during which the KMT candidate Ma Ying-jeou was elected as president of ROC. Upon completing data collection and coding, we will retest the hypotheses by using the expanded dataset.

22. It is beyond the scope of this aggregate data analysis to probe factors such as differences between mainland and native Taiwanese. Factors such as this one must await a more case-oriented, narrative-based approach.

\section{References}

Brody, Richard A., and Catherine R. Shapiro. 1989. "A Reconsideration of the Rally Phenomenon in Public Opinion." In Political Behavior Annual, ed. Samuel Long. Boulder: Westview Press.

Carpenter, Ted Galen. 2005. America's Coming War with China: A Collision Course over Japan. New York: Palgrave Macmillan.

Chambers, Michael R. 2002. "Rising China: A Threat to Its Neighbors?" In The Rise of China in Asia: Security Implications, ed. Carolyn W. Pumphrey. Carlisle Barracks, PA: Storming Media.

Chan, Steve. 2003. "Extended Deterrence in the Taiwan Strait: Learning from Rationalist Explanations in International Relations." World Affairs 166, 2 : 109-125.

Chiang Ching-kuo. 1979. The Republic of China Is on the Move. Hong Kong: Kwang Hwa Publishing.

Copper, John F. 1990. Nation-State or Province? Boulder: Westview Press. Coser, Lewis A. 1956. The Functions of Social Conflict. New York: Free Press.

DeRouen, Karl, Jr. 2000. "Presidents and the Diversionary Use of Force: A Research Note." International Studies Quarterly 44: 317-328.

Edwards, George C., and Alec M. Gallup. 1990. Presidential Approval: A Sourcebook. Baltimore: Johns Hopkins University Press.

Fordham, Benjamin O. 1998a. "Partisanship, Macroeconomic Policy, and U.S. Uses of Force, 1949-1994." Journal of Conflict Resolution 42: 418-439. 1998b. "The Politics of Threat Perception and the Use of Force: A Political Economy Model of U.S. Uses of Force, 1949-1994." International Studies Quarterly 42: 567-590.

2005. "Strategic Conflict Avoidance and the Diversionary Use of

Force." Journal of Politics 67: 132-153. 
Garrison, Jean A. 2005. Making China Policy: From Nixon to G. W. Bush. Boulder: Lynne Rienner.

Hickey, Dennis V. 2001. The Armies of East Asia: China, Taiwan, Japan, and the Koreas. Boulder: Lynne Rienner.

- 2007. Foreign Policy Making in Taiwan: From Principle to Pragmatism. New York: Routledge.

Hickey, Dennis V., and Yitan Li. 2002. "Cross-Strait Relations in the Aftermath of the Election of Chen Shui-bian." Asian Affairs: An American Review 28: 201-216.

James, Patrick. 1988. Crisis and War. Montreal: McGill-Queen's University Press.

James, Patrick, and John R. Oneal. 1991. "The Influence of Domestic and International Politics on the President's Use of Force." Journal of Conflict Resolution 35: 307-332.

James, Patrick, and Jean-Sébastien Rioux. 1998. "International Crises and Linkage Politics: The Experiences of the United States, 1953-1994." Political Research Quarterly 51: 781-812.

James, Patrick, and Enyu Zhang. 2005. "Chinese Choices: A Poliheuristic Analysis of Foreign Policy Crises, 1950-1996." Foreign Policy Analysis 1: 31-54.

Kang, David. 2007. China Rising: Peace, Power, and Order in East Asia. New York: Columbia University Press.

Kennedy, Peter. 1998. A Guide to Econometrics. 4th ed. Cambridge: MIT Press.

Kisangani, Emizet F., and Jeffrey Pickering. 2007. "Diverting with Benevolent Military Force: Reducing Risks and Rising Above Strategic Behavior." International Studies Quarterly 51: 277-299.

Kmenta, Jan. 1986. Elements of Econometrics. 2nd ed. New York: Macmillan.

Lai, Brian, and Dan Reiter. 2005. "Rally 'Round the Union Jack? Public Opinion and the Use of Force in the United Kingdom, 1948-2001." International Studies Quarterly 49: 255-272.

Lamborn, Alan C. 1991. The Price of Power: Risk and Foreign Policy in Britain, France, and Germany. Boston: Unwin Hyman.

Levy, Jack S. 1989. "The Diversionary Theory of War: A Critique.” In Handbook of War Studies, ed. Manus I. Midlarsky. Boston: Unwin Hyman.

Levy, Jack S., and William F. Mabe Jr. 2004. "Politically Motivated Opposition to War." International Studies Review 6: 65-83.

Lynch, Daniel C. 2006. Rising China and Asian Democratization: Socialization to "Global Culture" in the Political Transformations of Thailand, China, and Taiwan. Stanford: Stanford University Press.

Mastanduno, Michael, David A. Lake, and G. John Ikenberry. 1989. "Toward a Realist Theory of State Action." International Studies Quarterly 33: 457-474.

McClelland, Charles. 1999. World Event/Interaction Survey, 1966-1978. Ann Arbor, MI: Inter-University Consortium for Political and Social Research.

Meernik, James. 2000. "Modeling International Crises and the Political Use of Force by the USA." Journal of Peace Research 37: 547-562. 
Miller, Ross A. 1995. "Domestic Structures and the Diversionary Use of Force." American Journal of Political Science 39: 760-785.

Morgan, T. Clifton, and Christopher J. Anderson. 1999. "Domestic Support and Diversionary External Conflict in Great Britain, 1950-1992." Journal of Politics 61: 799-814.

Morgan, T. Clifton, and Kenneth Bickers. 1992. "Domestic Discontent and the External Use of Force." Journal of Conflict Resolution 36: 25-52.

Mueller, John E. 1973. War, Presidents, and Public Opinion. New York: Wiley. Narine, Shaun. 2008. "From Conflict to Collaboration: Institution-Building in East Asia." Behind the Headlines 65, 3: 1-22.

Ostrom, Charles W., and Brian Job. 1986. "The President and the Political Use of Force." American Political Science Review 80: 541-566.

Ostrom, Charles W., and Dennis Simon. 1985. "Promise and Performance: A Dynamic Model of Presidential Popularity." American Political Science Review 79: 334-338.

Pickering, Jeffrey, and Emizet F. Kisangani. 2005. "Democracy and Diversionary Military Intervention: Reassessing Regime Type and the Diversionary Hypothesis." International Studies Quarterly 49: 23-43.

Pindyck, Robert S., and Daniel L. Rubinfeld. 1981. Econometric Models and Economic Forecasts. 2nd ed. New York: McGraw-Hill.

Putnam, Robert D. 1988. "Diplomacy and Domestic Politics: The Logic of Two-Level Games.” International Organization 42: 427-460.

Redd, Steven B. 2005. "The Influence of Advisers and Decision Strategies on Foreign Policy Choices: President Clinton's Decision to Use Force in Kosovo." International Studies Perspectives 6: 129-150.

Rosenau, James N. 1969. Linkage Politics: Essays on the Convergence of National and International Systems. New York: Free Press.

Ross, Robert S. 2006. "Taiwan's Fading Independence Movement." Foreign Affairs 85: 141-148.

Russett, Bruce M. 1990. "Economic Decline, Electoral Pressure, and the Initiation of Interstate Conflict." In Prisoners of War? National-States in the Modern Era, ed. Charles S. Gochman and Alan Ned Sabrosky. Lexington, MA: Lexington Books.

Senese, Paul D. 2005. "Chinese Acquisition of the Spratly Archipelago and Its Implications for the Future." Conflict Management and Peace Science 22: 79-94.

Sprecher, Christopher, and Karl DeRouen Jr. 2002. "Israeli Military Action and Internationalization-Externalization Processes." Journal of Conflict Resolution 46: 149-164.

- 2005. "The Domestic Determinants of Foreign Policy Behavior in Middle Eastern Enduring Rivals, 1948-1998." Foreign Policy Analysis 1: 121-141.

Wu, Hsin-hsing. 1994. Bridging the Strait: Taiwan, China, and the Prospects for Reunification. New York: Oxford University Press.

Zhang, Baohui. 2008. "Taiwan's Political Balancing Act." Global Asia 3, 2: 82-89. 